\title{
Effect of Various Stabilizers on Viability of Lyophilized Pasteurella multocida B:3,4 for use as Hemorrhagic Septicemia Vaccine
}

\author{
Sajid Mahmood Sajid ${ }^{1}$, Arfan Yousaf ${ }^{1}$, Hamid Irshad ${ }^{2}$, Muhammad Arif Zafar' ${ }^{1}$ and Saif ur Rehman ${ }^{1}$ \\ ${ }^{1}$ Faculty of Veterinary and Animal Sciences, PMAS-Arid Agriculture University, Rawalpindi \\ ${ }^{2}$ Animal Health Program, Animal Sciences Institute, National Agricultural Research Center, Islamabad \\ *For correspondence: hamidirshad@hotmail.com \\ Received 29 September 2020; Accepted 21 November 2020; Published 25 January 2021
}

\begin{abstract}
Hemorrhagic septicemia (HS) is a devastating disease of cattle and buffaloes. The live aerosol vaccine is the best option to control HS. However, stability and viability of live vaccine is an issue. The present study was conducted to investigate the effect of three extraneous stabilizers trehalose, skimmed milk and lactalbumin on the viability of the live vaccine strain Pasteurella multocida B:3,4. The viability of the strain was evaluated using various concentrations (5, 10, 15 and $20 \%)$ of these three stabilizers. Moreover, viability of $P$. multocida B:3,4 was also determined at four different storage temperatures ($20,4,25$ and $37^{\circ} \mathrm{C}$ ). The duration of lyophilization cycle was also standardized for highest survival of cells. The data showed that trehalose and lactalbumin ensued percentage of viability as $91.89 \pm 0.08$ and $80.38 \pm 2.57$ respectively. Skimmed milk as stabilizer did not prove to defend cells during lyophiliztion and subsequent storage and exhibited cell viability approximately $0.47 \pm 0.009 \%$. The study indicated that most effective stabilizer for lyophiliztion of $P$. multocida B:3,4 was trehalose at $15 \%$ concentration and was most suitable temperature for storage of lyophilized P. multocida B:3,4. (C) 2021 Friends Science Publishers
\end{abstract}

Keywords: Stabilizers; Pasteurella multocida; Viability; Lyophilization; Trehalose; Skimmed Milk; Lactalbumin

\section{Introduction}

Hemorrhagic septicemia is a short course, lethal and septicemic disease of buffaloes and cattle caused by a Gram negative, non-motile, coccobacillus bacterium, the Pasteurella multocida (Boyce et al. 2000). HS is a main epizootic disease in cattle and buffaloes in several countries with high morbidity and mortality (El-Jakee et al. 2016). In Asia, HS has caused severe economic losses (Benkirane and De Alwis 2002; Abba et al. 2017).

Treatment of HS with antibiotics is prolonged, expensive and ineffective because of emerging resistance of antibiotics against $P$. multocida. The use of antibiotics might cause toxicity to human consumers. Acute nature of HS is another hindrance in treatment (Ahmad et al. 2014). Different vaccine types including oil adjuvanted, multiple emulsion and alum precipitated vaccines are used to control this fatal disease. Killed vaccines have been extensively used against HS in the world (Shivachandra et al. 2011). Nonetheless, these injectable vaccines are difficult to administer as restraining the animals has been found to be very difficult (Sarah 2007). Moreover, oil adjuvant vaccine is fairly disliked by farmers because it possesses dense viscosity (Sarah et al. 2006; De Alwis 1992). The application of live vaccine that can be given intra-nasally is a substitute method to save the animals from HS.

Live vaccines have played a pivotal part from the start of immunology (Detmer and Glenting 2006). Yet, there has been failure to develop vaccine having greater viable inhabitants of live microorganism for protection from disease. Thus, the initiation of an effective and systematic formulation approach is critical to increase survival rate, storage stability and bacterial cell activity in live vaccine. Freeze-drying or lyophilization is a convenient technique to conserve bacteria and viruses by dehydrating cellular fluid (Das et al. 2018). The purpose of lyophilization is to convert bacteria in a stable form which can be stored for a longer period of time. Moreover, it is mainly required to attain high viability of cells (Winters and Winn 2010). At present, freeze drying is a frequently used method for this purpose. It has been reported that many strains of bacteria have shown better survival rates after lyophilization for long storage duration (Peiren et al. 2015). This biophysical process is relatively comfortable and generally used for cultural collection of microorganisms. The discovery also narrates the way for preparing a stabilized product, vaccine (Morgan et al. 2006). However, this method might render the microorganisms to extra stressful operational steps therefore 
dropping their viability (Saarela et al. 2005; Schoug et al. 2006). The procedure principally involves freezing, sublimation and lastly desorption of the water molecules from the microorganisms (Stephan et al. 2016). Process of Freeze drying contains three basic steps: first is the freezing, second is primary drying and third is secondary drying. During the first step, the freezing, water is transformed into ice, generally entrapped in the amorphous medium of the lyoprotectant, a material that prevents cells from damage throughout this process. The freezing temperature of amorphous lyoprotectant must be below its glass transition temperature (Tg') to make sure an entirely solid product. During the primary drying, ice is eliminated through sublimation. When the primary drying temperature of the product is excessively high (i.e., above the collapse temperature $\mathrm{Tc}$ ), the porous product can disintegrate, therefore high temperature should be avoided (Fonseca $e t$ al. 2004). During secondary drying, remaining unfrozen water captured in the glassy medium is eliminated by isothermal desorption. The endpoint of the secondary drying step is set to get preferred residual moisture content (RMC). Death or inactivation of freeze-dried bacterial cells during storage is reliant on water activity (aw), storage temperature and residual moisture content (Aschenbrenner et al. 2012; Passot et al. 2012).

Protectant gives steadiness and safety against further inactivating processes such as protein denaturation which is relatively sensitive and reduces viability of several cell types (Carvalho et al. 2004). For the ease of use and to ensure that the vaccine product is in its optimum functional and efficient form, various sugars for instance lactose, sucrose, glucose and trehalose have been frequently used as protective means (Hubalek 2003). Apart from, skimmed milk and nitrogen compounds such as peptone, yeast extract and casein hydrolysate have also been studied (Berny and Hennebert 1991). These protective agents perpetually play a pivotal part in consenting cells to be managed for storage at deep temperatures and to be restored with suitable viability (Elliott et al. 2017).

In this study, three different stabilizers: trehalose, lactalbumin and skimmed milk were used to evaluate viability of $P$. multocida B:3,4 strain during freeze drying process. Furthermore, combination of these stabilizers in suitable concentrations was also used for this purpose. The conservation of cell viability is first and foremost requirement to produce a live vaccine because vaccination is an effective and economical practice to prevent infectious diseases. The present study was conducted to evaluate the effect of three stabilizers to conserve the viability of $P$. multocida B:3,4 during lyophilization and subsequent storage at four different temperatures. This stability study of $P$. multocida B:3,4 will play a key role for the determination of suitable stabilizer and storage temperature that ensure the safety, efficacy and viability of live HS vaccine.

\section{Materials and Methods}

\section{Source of the strain}

The strain of $P$. multocida B:3,4 was retrieved from the inventory at $-20^{\circ} \mathrm{C}$ maintained at Bacteriology laboratory of Animal Health Program, Animal Sciences Institute, National Agricultural Research Center (NARC), Islamabad.

\section{Revival and growth of microorganisms}

Mice inoculation method was used to revive $P$. multocida B:3,4. The method was adopted according to Singh et al. (2010) with minor modifications. Swiss albino mice $(n=5)$ were purchased from Animal House, National Institute of Health (NIH), Islamabad. The mice were kept and reared in lab animal house, Animal Health Program, NARC, Islamabad. These mice were divided into two groups, Group-I $(\mathrm{n}=2)$ and Group-II $(\mathrm{n}=3)$. Lyophilized $P$. multocida B: 3,4 strain was reconstituted in $1 \mathrm{~mL}$ normal saline ( $\mathrm{pH}=7.2)$. Reconstituted strain was streaked on tryptic soya agar (TSA) and incubated at $37^{\circ} \mathrm{C}$ for $18 \mathrm{~h}$. After incubation Group-I was injected intraperitoneal with $200 \mu \mathrm{L}$ of $10^{-5}$ dilution $P$. multocida $\mathrm{B}: 3,4$ culture. Group-II was injected with $200 \mu \mathrm{L}$ of normal saline solution. After $24 \mathrm{~h}$, inoculated mice were found dead. However, mice of control group remained alive. The dead mice were dissected and spleen and heart were collected aseptically. Morbid organs (heart and spleen) were used to streak on blood agar. Heart blood was also collected and used for streaking on blood agar. These streaked plates were incubated for $24 \mathrm{~h}$ at $37^{\circ} \mathrm{C}$. After incubation, the resultant colonies were identified by Gram's staining. The isolated colonies were selected and harvested on blood agar. The plates were incubated at $37^{\circ} \mathrm{C}$ for $24 \mathrm{~h}$ to get pure cultures. Different biochemical tests, differential media i.e; MacConkey agar and PCR were used (Zhao et al. 2019) for confirmation of $P$. multocida strain B: 3,4.

\section{Preparation of stabilizer media}

Three stabilizers, trehalose (Sigma-Aldrich Co), lactalbumin (Neogen Corporation, Michigan) and skimmed milk (Neogen Corporation, Michigan) were selected (Gehrke et al. 1992; Conrad et al. 2000; Chen and Kristensen 2009) to check their effect on viability of $P$. multocida B:3,4. They were evaluated using 5, 10, 15 and $20 \%$ concentrations (Oslan et al. 2017; Bassiouny et al. 2019). To prepare stabilizer media, desired concentrations of stabilizers namely skimmed milk, lactalbumin and trehalose were suspended in distilled water. Skimmed milk and lactalbumin were autoclaved at $121^{\circ} \mathrm{C}$ for 15 min before mixing with the P. multocida B:3,4. Trehalose was sterilized by filtration using microfilter having pore size $0.20 \mu \mathrm{m}$. A control was prepared by suspending $P$. multocida $\mathrm{B}: 3,4$ with autoclaved distilled water. 


\section{Preparation of bacterial suspension}

Bacterial suspension was prepared by inoculating pure culture of $P$. multocida B:3,4 in tryptic soya broth (TSB). Suspension was vortexed for few seconds to make it homogenous. Afterward, suspension was incubated at $37^{\circ} \mathrm{C}$ for half an hour.

\section{Viability before lyophilization}

Equal volumes (1:1) of desired concentrations (Bora et al. 2015) of stabilizers and P. multocida B: 3,4 enriched in TSB were mixed in $5 \mathrm{~mL}$ freeze drying vials $(1 \mathrm{~mL}$ filled volume). The viability of samples before freeze drying was determined by Miles and Misra method (Miles et al. 1938) and expressed as colony forming units (CFUs) per $\mathrm{mL}$. Suspensions were frozen in glass vials by keeping at $-80^{\circ} \mathrm{C}$ for at least one hour before lyophilization.

\section{Lyophilization}

Process of lyophilization (freeze drying) was completed in $48 \mathrm{~h}$ cycle. Suspension of $P$. multocida B: 3,4 was cooled in a shelf at a linear ramp rate in pilot scale lyophilizer (Ilshin BioBase, Europe). A conventional freeze-drying process completes in three steps; freezing, primary drying and secondary drying (Tang and Pikal 2004). After completion of lyophilization, the viability of lyophilized samples of $P$. multocida B: 3,4 was determined using Miles and Misra Method (Miles et al. 1938) and stated as CFU/mL.

\section{Storage at different temperatures}

Lyophilized vaccine was stored at different temperatures i.e., $-20,4,25$ and $37^{\circ} \mathrm{C}$ to check the effect of temperature on viability of $P$. multocida in various stabilizers (Oslan $e t$ al. 2017).

\section{Revival, enumeration and determination of cell viability}

The viability of cells after lyophilization was calculated as CFU. Three vials of each concentration were taken to determine viability i.e. readings were taken in triplicate to calculate mean. Before determining CFUs, freeze dried samples were reconstituted by adding $1 \mathrm{~mL}$ phosphate buffer saline (PBS) adjusted at pH 7.2. To get homogenous solution, the samples were vortexed and then incubated at $37^{\circ} \mathrm{C}$ for $30 \mathrm{~min}$ to make sure the absolute dissolution of bacterial material and PBS. Miles and Misra method (Miles et al. 1938) was adopted to determine CFUs. Briefly, lyophilized vaccine was reconstituted in $1 \mathrm{~mL}$ PBS $(\mathrm{pH}$ 7.2). Then vaccine was vortexed for few seconds to obtain homogenous suspension. The reconstituted vaccine $(1 \mathrm{~mL})$ was added to $9 \mathrm{~mL}$ of PBS to make serial dilutions up to $10^{-}$ ${ }^{10}$. From each serial dilution, $20 \mu \mathrm{l}$ was inoculated on TSA in triplicate. The plates were kept undisturbed until inoculated suspension was completely immersed by the agar. Plates were then incubated for $24 \mathrm{~h}$ at $37^{\circ} \mathrm{C}$. After incubation, the number of colonies was calculated. The percentage of viable cells was estimated using following equation:

Percentage (\%)viability $=\frac{\text { Cell viability after lyophilization }\left(\frac{\mathrm{CFU}}{\mathrm{ml}}\right)}{\text { Cell viability before lyophilization }\left(\frac{\mathrm{CFU}}{\mathrm{ml}}\right)} \times 100$

\section{Results}

Effect of duration of lyophilization on viability of $\boldsymbol{P}$. multocida $\mathrm{B}: 3,4$

Initially, lyophilization was conducted for $24 \mathrm{~h}$. After $24 \mathrm{~h}$, vials were removed from lyophilized and observed. Lyophilization involves conversion of microorganisms from a liquid state to a solid compact mass however using $24 \mathrm{~h}$ duration partial lyophilization with moisture contents was found. It indicated that $24 \mathrm{~h}$ duration was not able to convert the bacterial suspension into a compact mass. Hence, one more freeze-drying cycle of total $48 \mathrm{~h}$ was tried aimed to attain homogenous freeze-dried mass. The vials after $48 \mathrm{~h}$ freeze drying showed compact mass with no moisture contents which indicated the complete lyophilization. Results of viability of both cycles are explained in Table 1. First cycle of freeze drying using $24 \mathrm{~h}$ duration was found unable to protect the viability of $P$. multocida $\mathrm{B}: 3,4$ and caused substantial loss of viability. The survival rates were reduced to $0 \%$. The survival rate of cells was significantly higher using $48 \mathrm{~h}$ duration with different stabilizers. Results indicated that amongst protective agents, trehalose, skimmed milk and lactalbumin at the concentration of $5 \%$ the percentage of viability was $32.39 \% \pm 1.9,0.036 \% \pm 0.002$ and $26.08 \% \pm 0.81$ while at the $10 \%$ concentration survival rate was $47.22 \% \pm 1.19,0.58 \% \pm 0.02$ and $31.42 \% \pm 0.62$ percent respectively (Table 1). The $15 \%$ concentration showed survival rates for trehalose, skimmed milk and lactalbumin corresponding to percentage viability of $89.87 \% \pm 1.53$, $0.81 \% \pm 0.020$ and $81.81 \% \pm 1.42$ respectively. On the other hand, the $20 \%$ concentration of trehalose, skimmed milk and lactalbumin showed percentage of viability $82.89 \% \pm 2.3$, $0.82 \% \pm 0.024$ and $76.92 \% \pm 2.02$ respectively. The stabilizers demonstrated maximum viability after freeze drying at the concentration of $15 \%$ using $48 \mathrm{~h}$ duration of lyophilization. For this reason, $15 \%$ concentration of all stabilizers was used in succeeding investigation.

\section{Effect of stabilizers on viability of $P$. multocida $B: 3,4$}

The survival rate of $P$. multocida $\mathrm{B}: 3,4$ with three different stabilizers at $15 \%$ concentrations after lyophilization is shown in Table 2 . The highest percentage $(91.89 \% \pm 0.08)$ of viable cells was attained with $15 \%(\mathrm{w} / \mathrm{v})$ trehalose as the stabilizer. Lactalbumin (15\%, w/v) showed an agreeable percentage of viability as $80.38 \% \pm 2.57$. Skimmed milk as stabilizer did not prevent the viable cells from damaging 
Sajid et al. / Intl J Agric Biol, Vol 25, No 3, 2021

Table 1: Effect of freeze-drying cycle on the viability of $P$. multocida B:3,4 using three different stabilizers i.e., trehalose, lactalbumin and skimmed milk

\begin{tabular}{|c|c|c|c|c|c|}
\hline Duration of freeze-drying cycle & Protective agent & Percentage used & Before freeze drying $(\mathrm{CFU} / \mathrm{ml})$ & After freeze drying (CFU/ml) & $\%$ of viability \pm S.D \\
\hline \multirow[t]{13}{*}{$24 \mathrm{~h}$} & \multirow[t]{2}{*}{ Distilled water } & Control & $7.3 \times 10^{10}$ & $4.2 \times 10^{4}$ & $0.000057 \pm 2.1 \times 10^{-6}$ \\
\hline & & $5 \%$ & $7.4 \times 10^{10}$ & $4.4 \times 10^{5}$ & $0.00059 \pm 1.4 \times 10^{-5}$ \\
\hline & \multirow{3}{*}{ Trehalose } & $10 \%$ & $6.7 \times 10^{10}$ & $8.4 \times 10^{4}$ & $0.00012 \pm 0$ \\
\hline & & $15 \%$ & $7.1 \times 10^{10}$ & $8.0 \times 10^{6}$ & $0.011 \pm 0.0008$ \\
\hline & & $20 \%$ & $6.5 \times 10^{10}$ & $7.6 \times 10^{4}$ & $0.00011 \pm 4.7 \times 10^{-6}$ \\
\hline & \multirow[t]{4}{*}{ Skimmed Milk } & $5 \%$ & $6.4 \times 10^{10}$ & $4.1 \times 10^{4}$ & $0.000064 \pm 3.09 \times 10^{-6}$ \\
\hline & & $10 \%$ & $7.2 \times 10^{10}$ & $4.4 \times 10^{4}$ & $0.000061 \pm 1.4 \times 10^{-6}$ \\
\hline & & $15 \%$ & $7.8 \times 10^{10}$ & $6.2 \times 10^{5}$ & $0.00079 \pm 1.6 \times 10^{-5}$ \\
\hline & & $20 \%$ & $7.9 \times 10^{10}$ & $5.1 \times 10^{4}$ & $0.000064 \pm 4.7 \times 10^{-7}$ \\
\hline & \multirow[t]{3}{*}{ Lactalbumin } & $10 \%$ & $7.9 \times 10^{10}$ & $4.3 \times 10^{4}$ & $0.000054 \pm 2.4 \times 10^{-6}$ \\
\hline & & $15 \%$ & $7.4 \times 10^{10}$ & $6.3 \times 10^{5}$ & $0.00085 \pm 1.2 \times 10^{-5}$ \\
\hline & & $20 \%$ & $6.1 \times 10^{10}$ & $3.7 \times 10^{4}$ & $0.000060 \pm 1.6 \times 10^{-6}$ \\
\hline & \multirow[t]{2}{*}{ Distilled water } & Control & $7.4 \times 10^{10}$ & $4.6 \times 10^{4}$ & $0.000062 \pm 2.8 \times 10^{-6}$ \\
\hline \multirow[t]{11}{*}{$48 \mathrm{~h}$} & & $5 \%$ & $7.1 \times 10^{10}$ & $2.3 \times 10^{10}$ & $32.39 \pm 1.9$ \\
\hline & \multirow{3}{*}{ Trehalose } & $10 \%$ & $7.2 \times 10^{10}$ & $3.4 \times 10^{10}$ & $47.22 \pm 1.19$ \\
\hline & & $15 \%$ & $7.8 \times 10^{10}$ & $7.1 \times 10^{10}$ & $89.87 \pm 1.53$ \\
\hline & & $20 \%$ & $7.6 \times 10^{10}$ & $6.3 \times 10^{10}$ & $82.89 \pm 2.3$ \\
\hline & \multirow[t]{3}{*}{ Skimmed Milk } & $5 \%$ & $6.6 \times 10^{10}$ & $2.3 \times 10^{7}$ & $0.036 \pm 0.002$ \\
\hline & & $15 \%$ & $7.6 \times 10^{10}$ & $6.2 \times 10^{8}$ & $0.81 \pm 0.020$ \\
\hline & & $20 \%$ & $7.5 \times 10^{10}$ & $6.2 \times 10^{8}$ & $0.82 \pm 0.024$ \\
\hline & \multirow[t]{4}{*}{ Lactalbumin } & $5 \%$ & $6.9 \times 10^{10}$ & $1.8 \times 10^{10}$ & $26.08 \pm 0.81$ \\
\hline & & $10 \%$ & $7.0 \times 10^{10}$ & $2.2 \times 10^{10}$ & $31.42 \pm 0.62$ \\
\hline & & $15 \%$ & $7.7 \times 10^{10}$ & $6.3 \times 10^{10}$ & $81.81 \pm 1.42$ \\
\hline & & $20 \%$ & $7.8 \times 10^{10}$ & $6.0 \times 10^{10}$ & $76.92 \pm 2.02$ \\
\hline
\end{tabular}

Table 2: The viability of $P$. multocida B:3,4 cells formulated with $15 \%(\mathrm{w} / \mathrm{v})$ of protective agents (trehalose, lactalbumin and skimmed milk) after freeze drying

\begin{tabular}{|c|c|c|c|}
\hline \multirow{2}{*}{$\begin{array}{l}\text { Protective agent } \\
(15 \% \mathrm{w} / \mathrm{v})\end{array}$} & \multicolumn{2}{|c|}{ Viable cells CFU/mL } & \multirow[t]{2}{*}{ Percentage of viability $\pm \mathrm{S}$. D } \\
\hline & Before freeze drying & After freeze drying & \\
\hline Distilled water (control) & $7.8 \times 10^{10}$ & $3.2 \times 10^{6}$ & $0.004 \pm 0$ \\
\hline Trehalose & $7.4 \times 10^{10}$ & $6.8 \times 10^{10}$ & $91.89 \pm 0.08$ \\
\hline Skimmed Milk & $7.2 \times 10^{10}$ & $3.5 \times 10^{8}$ & $0.47 \pm 0.009$ \\
\hline Lactalbumin & $7.6 \times 10^{10}$ & $6.1 \times 10^{10}$ & $80.38 \pm 2.57$ \\
\hline Trehalose $(15 \%)+$ skimmed milk $(15 \%)$ & $7.5 \times 10^{10}$ & $3.2 \times 10^{10}$ & $43.1 \pm 0.86$ \\
\hline
\end{tabular}

Table 3: Viability of freeze dried P. multocida B:3, 4 cells using three different protective agents (trehalose, lactalbumin and skimmed milk) during storage at $-20^{\circ} \mathrm{C}, 4^{\circ} \mathrm{C}, 25^{\circ} \mathrm{C}$ and $37^{\circ} \mathrm{C}$ for 30 days

\begin{tabular}{|c|c|c|c|c|c|c|c|c|c|c|c|c|}
\hline \multirow{2}{*}{ Protective agent $(15 \% \mathrm{w} / \mathrm{v})$} & \multicolumn{4}{|c|}{ Day 0} & \multicolumn{8}{|c|}{ Day 30} \\
\hline & $-20^{\circ} \mathrm{C}$ & $4^{0} \mathrm{C}$ & $25^{\circ} \mathrm{C}$ & $37^{\circ} \mathrm{C}$ & $-20^{\circ} \mathrm{C}$ & $\%$ viability \pm S.D & $4^{0} \mathrm{C}$ & $\%$ viability \pm S.D & $25^{\circ} \mathrm{C}$ & $\%$ viability \pm S.D & $37^{\circ} \mathrm{C}$ & $\%$ viability \pm S.D \\
\hline Distilled water & $3.4 \times 10^{7}$ & $3.5 \times 10^{7}$ & $3.3 \times 10^{7}$ & $3.5 \times 10^{7}$ & 0 & 0 & 0 & 0 & 0 & 0 & 0 & 0 \\
\hline Trehalose & $6.2 \times 10^{10}$ & $6.6 \times 10^{10}$ & $6.3 \times 10^{10}$ & $6.3 \times 10^{10}$ & $5.4 \times 10^{10}$ & $84.91 \pm 2.5$ & $3.4 \times 10^{10}$ & $52.50 \pm 2.79$ & $6.1 \times 10^{9}$ & $9.74 \pm 0.41$ & $5.3 \times 10^{8}$ & $0.84 \pm 0.04$ \\
\hline Skimmed Milk & $6.6 \times 10^{10}$ & $6.3 \times 10^{10}$ & $6.4 \times 10^{10}$ & $6.7 \times 10^{10}$ & $3.7 \times 10^{8}$ & $0.55 \pm 0.009$ & $2.6 \times 10^{5}$ & $0.00041 \pm 2.05 \times 10^{-5}$ & 0 & 0 & 0 & 0 \\
\hline Lactalbumin & $6.1 \times 10^{10}$ & $6.2 \times 10^{10}$ & $6.4 \times 10^{10}$ & $6.1 \times 10^{10}$ & $4.5 \times 10^{10}$ & $73.36 \pm 2.03$ & $2.3 \times 10^{10}$ & $37.81 \pm 3.7$ & $3.3 \times 10^{9}$ & $5.22 \pm 0.16$ & 0 & 0 \\
\hline Trehalose+ skimmed milk & $6.7 \times 10^{10}$ & $6.4 \times 10^{10}$ & $6.5 \times 10^{10}$ & $6.3 \times 10^{10}$ & $2.6 \times 10^{10}$ & $38.87 \pm 4.13$ & $6.2 \times 10^{9}$ & $9.68 \pm 0.33$ & $5.2 \times 10^{6}$ & $0.0079 \pm 4.7 \times 10^{-5}$ & 0 & 0 \\
\hline
\end{tabular}

effects of freeze-drying process. There was an enormous difference of viable cells of $P$. multocida B:3,4 after lyophilization using skimmed milk as stabilizer. The viability in skimmed milk was $0.47 \% \pm 0.009$ after freeze drying. Additionally, skimmed milk (15\%) was mixed with trehalose $(15 \%)$ to check the combined effect of both stabilizers on viability. The percentage of CFUs was markedly improved $(43.1 \% \pm 0.86)$ as compared to skimmed milk when it was used alone as cryoprotectant $(0.47 \% \pm 0.009)$. However, cell viability of lyophilized cells using combination of both stabilizers was still too inferior to use as protective agent. The findings of this experiment proposed that skimmed milk alone or its combination with trehalose is not appropriate for the conservation of viability of $P$. multocida B:3,4 during lyophilization procedure. However, trehalose was the only protectant that showed highest survival rate in this study. Therefore, from these results, it can be demonstrated that trehalose, a disaccharide, is effective to be used as stabilizer during freeze drying of $P$. multocida $\mathrm{B}: 3,4$.

\section{Effect of storage temperature on survival rate of lyophilized $P$. multocida B:3,4}

After rehydration in PBS, freeze dried P. multocida B:3,4 in three stabilizers was stored at four different temperatures $20,4,25$ and $37^{\circ} \mathrm{C}$ to check the survival rate. Three vials for each temperature were stored to take readings in triplicate. The viability of $P$. multocida B:3,4 before freeze drying in the protective agents at day zero and day 30 after storage at $-20,4,25$ and $37^{\circ} \mathrm{C}$ was checked. The results (Table 3) showed that $84.91 \pm 2.5$ of cells remained viable at $-20^{\circ} \mathrm{C}$ using trehalose $15 \%(\mathrm{w} / \mathrm{v})$ as stabilizer after onemonth storage. The $4{ }^{\circ} \mathrm{C}$ storage temperature showed 
$52.50 \% \pm 2.79$ of survival rate with same protective agent. Whereas other two storage temperatures 25 and $37^{\circ} \mathrm{C}$ showed viability of $9.74 \% \pm 0.41$ and $0.84 \% \pm 0.04$ respectively. Lactalbumin $(15 \%, \mathrm{w} / \mathrm{v})$ showed viability of $73.36 \% \pm 2.03$ at $-20^{\circ} \mathrm{C}$ storage temperature while at $4^{\circ} \mathrm{C}$ survival rate was $37.81 \% \pm 3.7$. The viability was found very low $(5.22 \% \pm 0.16)$ at $25^{\circ} \mathrm{C}$ and at $37^{\circ} \mathrm{C}$ it dropped to $0 \%$ in lactalbumin $(15 \%)$. The results showed that skimmed milk $(15 \%, w / v)$ was unable to protect the viable cell at all four storage temperatures. After one-month storage at -20, 4, 25 and $37^{\circ} \mathrm{C}$ in skimmed milk, the viability declined to $0 \%$. When a combination of skimmed milk (15\%) and trehalose $(15 \%)$ was used, comparatively an enhanced survival rate was obtained $(38.87 \% \pm 4.13)$ at $-20^{\circ} \mathrm{C}$ as compared to viability of individual skimmed milk $(0.55 \% \pm 0.009)$. However, this combination showed very low survival rates at $4^{\circ} \mathrm{C}(9.68 \% \pm 0.33)$ while results at 25 and $37^{\circ} \mathrm{C}$ revealed that viability has been declined to $0 \%$. These results demonstrated that different storage temperatures significantly affected the viability of $P$. multocida $\mathrm{B}: 3,4$ in various protective agents. It was obvious that among all these storage temperatures, $-20^{\circ} \mathrm{C}$ is most suitable storage temperature to conserve viability following $4^{\circ} \mathrm{C}$ temperature. Whereas, 25 and $37^{\circ} \mathrm{C}$ have detrimental effects on survival rate of $P$. multocida $\mathrm{B}: 3,4$. Among three stabilizers, trehalose was found the most appropriate stabilizer that achieved highest survival rate of $P$. multocida B:3,4 after 30 days storage at $-20^{\circ} \mathrm{C}$ and showed the least viability reduction from $6.4 \times 10^{10}$ to $5.4 \times 10^{10} \mathrm{CFU} / \mathrm{mL}$. Our results showed that trehalose provided protective effect on lyophilized $P$. multocida B:3,4 at $-20^{\circ} \mathrm{C}$. Therefore, trehalose is the best stabilizer to conserve viability of $P$. multocida $\mathrm{B}: 3,4$ and $-20^{\circ} \mathrm{C}$ is most suitable storage temperature of for this microorganism. Consequently, trehalose was selected as stabilizer to prepare live aerosol HS vaccine and storage temperature $-20^{\circ} \mathrm{C}$ was selected for preservation.

\section{Discussion}

To our knowledge, this is first study on effect of stabilizers and storage temperature explaining viability of freeze-dried P. multocida B:3,4. Use of bacterial cells as live vaccine for disease prevention depends on the conservation and preservation of viable cells which are required to ensure long term delivery of stable vaccine in terms of viability (Jain et al. 2020). Therefore, a live vaccine targets include specific number of CFUs, conservation of live cells during lyophilization, and retaining the viability during production procedure and storage (Saarela et al. 2000; Lacroix and Yildirim 2007; Mahapatra et al. 2020). The delivery, storing and use of vaccines consequently present challenges that could be reduced by enhanced stability achieved by lyophilization and adding stabilizers with resulting betterment in vaccine efficiency. The aim of this work was to assess the protective effect and suitable concentrations of trehalose, skimmed milk and lactalbumin during lyophilization and storage of $P$. multocida B:3,4 to develop live HS vaccine. The selection of protectant for specific organism that might preserve viability during lyophilization and storage is essential. In this study trehalose, skimmed milk and lactalbumin were selected because these most commonly used stabilizers are able to protect viability of the vaccines during lyophilization and even during storage after rehydration with diluent (Gehrke et al. 1992; Conrad et al. 2000; Chen and Kristensen 2009; Bellali et al. 2020). Moreover, these three stabilizers are widely used to conserve number of organisms (Zhang and Hui 2017; Latif et al. 2018). The studies on stability of microorganisms have shown that these three stabilizers contain protective effects on the viability of microorganisms (Mariner et al. 2017; Bora et al. 2018). Therefore, these stabilizers were selected on the basis of previous studies on several other bacteria.

The results from duration of lyophilization showed that $48 \mathrm{~h}$ cycle of freeze drying was the most appropriate approach as compared to $24 \mathrm{~h}$ duration. The percentage of viable cells was significantly greater in cycle of $48 \mathrm{~h}$ duration. The primary drying step in freeze drying is conversion of liquid culture into ice-crystals and then to remove ice in the form of vapors (Nireesha et al. 2013; Pansare and Patel 2019). In cycle 1 (24 h), time for removal of ice crystals during lyophilization was shorter than cycle 2 $(48 \mathrm{~h})$ which was resulted in the development of ice residuals that appeared in the form of moisture in $P$. multocida B:3,4 during $24 \mathrm{~h}$ duration (Saclier et al. 2010). A previous study conducted by Oslan et al. (2017) to evaluate the effect of different stabilizers on the viability of mutant $P$. multocida $\mathrm{B}: 2$ cells after lyophilization process using two different time durations of cycles also indicated that freeze drying duration of $54 \mathrm{~h}$ was the most appropriate approach in preserving cell viability of mutant $P$. multocida B:2 compared to cycle of $24 \mathrm{~h}$ duration. Consequently, a sufficient time period for freeze drying process is important to ensure complete lyophilization and conservation of viable cells to produce live vaccine.

Stabilizers and their concentrations significantly affect the viability of micro-organisms during freeze drying (Zhao and Zhang 2005; Shokri et al. 2019). The results of this study also indicated that viability of $P$. multocida $\mathrm{B}: 3,4$ after freeze drying was different with various stabilizers. The highest viability of $P$. multocida B:3,4 was observed when $15 \%$ trehalose was used as stabilizer. Previous studies also reported high viability of Salmonella enterica, Lactobacillus salivarius and Pseudoalteromonas nigrifaciens after freeze drying when trehalose was used as stabilizer compared to lactose, sucrose, sorbitol, lactalbumin, skimmed milk and ascorbic acid (Zayed and Roos 2004; Kang et al. 2010; Zhang et al. 2020). Trehalose is considered an excellent osmolyte with remarkable stabilizing effects on cells and preserves the viability of cells in freeze dried as well as in solution state (Kaushik and Bhat 2003). Other earlier investigations have also directed that trehalose prolongs the 
stability of several vaccines (Bora et al. 2015). When microorganisms are exposed to stress, trehalose helps them in retaining cellular integrity. This is thought to occur by prevention of denaturation of proteins by trehalose, which would otherwise degrade under stress (Jain and Roy 2009). Other stabilizers possess low or lack this ability. A potential fact for the significant defensive effect of trehalose to viable cells' plasma membrane and protein is by removing water in plasma membrane removed during the freeze-drying procedure and prevent unfolding and aggregating proteins by the formation of hydrogen bonds with polar groups of proteins (Leslie et al. 1995; Crowe et al. 2001; Bellali et al. 2020). It has been demonstrated that the trehalose would defend cell proteins against denaturation (Guowei et al. 2019). More important, trehalose penetrates the cells and reduces the damaging effects of osmosis during water loss and prevents the development of ice crystals and resultant breakdown of plasma membrane (Cota and Alvim 2018). Concentration of the stabilizer considerably affects the viability of microorganisms during lyophilization. For example, lower concentration of stabilizer may not be able to form required hydrogen bonds to provide protection against negative effects of freeze drying (Mensink et al. 2017). Similarly, higher concentration of stabilizers may prove toxic to cells thus lowering viability (Bhattacharya 2018). Therefore, optimization of stabilizer concentration for optimum cell viability is essential.

The results from investigations on the storage of $P$. multocida B: 3,4 with selected stabilizers at four different temperatures revealed that the highest viability was obtained at storage temperature of $-20^{\circ} \mathrm{C}$ in $15 \%$ trehalose after onemonth storage. Similar to our findings Oslan et al. (2017) also reported that the survival of $P$. multocida B: 2 was highest at $-30^{\circ} \mathrm{C}$ compared to $4^{\circ} \mathrm{C}$ and $27^{\circ} \mathrm{C}$ after 6-month storage at three different storage temperatures. In our studies, trehalose at the concentration of $15 \%$ retained highest cell viability at storage temperature $-20^{\circ} \mathrm{C}$ while lactalbumin $(15 \%)$ at the same temperature also showed reasonable viability. Though, skimmed milk failed to conserve viability and reduced the viability to zero percent at all four storage temperatures. Our results also agree with previous work of Bolla et al. (2011). However, a combination of trehalose and skimmed milk improved the cell viability after storage at $-20^{\circ} \mathrm{C}$. Similarly, in previous studies, Malik et al. (1993); Kanmani et al. (2011); Oslan et al. (2017) and Archacka et al. (2019) also used combination of these two stabilizers and found the increased cell viability. The protectants in combination may suppress each other or they may develop an additive or synergistic effect (Guowei et al. 2019). In our case, it has been observed that the effect of skimmed milk using such combination was superior to individual but percentage of cell viability was too low to use as protectant.

These results indicated that the storage temperature $20^{\circ} \mathrm{C}$ was the most pertinent temperature that conserved highest viability. In this study, difference in viability of cells exhibited that certain stabilizers are more effective than others to protect the $P$. multocida B: 3,4 . The effect of storage temperature on viability is due to the fact that in response to different temperatures, breakdown of membrane and other proteins in bacterial cells occurs that affects the viability (Gur et al. 2011; Liu et al. 2019). Zeng et al. (2009) has also suggested that loss of viability is consequence of temperature induced plasma membrane damage. As a result, the irreversible damage to bacterial cell membrane leads to unviable cells (Cota and Alvim 2018).

\section{Conclusion}

The viability of $P$. multocida $\mathrm{B}$ : 3,4 during lyophilization and subsequent storage is dependent on the selection of stabilizer. The selection of a suitable protective medium and storage temperature is crucial to attain highest percentage of viability as it is the main factor that affects the stability of the live vaccines. In our studies, during freeze drying process and subsequent storage of $P$. multocida B: 3,4, we found that trehalose was the most appropriate protectant that greatly influenced the survival rate of $P$. multocida $\mathrm{B}: 3,4$. The highest survival rates of $P$. multocida $\mathrm{B}$ : 3,4 were observed when cells were lyophilized and stored at $-20^{\circ} \mathrm{C}$, which is the optimum storage temperature for preservation of $P$. multocida $\mathrm{B}: 3,4$. The most effective concentration of trehalose was $15 \%$ in this study. Consequently, for storage of $P$. multocida B: 3,4 live aerosol HS vaccine, trehalose can be added as protectant. Moreover, duration of freezedrying cycle also significantly affected the survival rate of cells and therefore it should be optimized and confirmed to ensure that final vaccine contains required number of live cells. These findings would help in development of live aerosol HS vaccine. Development of live aerosol vaccine would contribute to prevent animals from HS. However, still there is a need for evaluation and standardization of a stabilizer that keeps the live aerosol vaccine stable and viable at room temperature.

\section{Acknowledgement}

Authors thank Agricultural Linkages Program, PARC (Project No: AS-142) for financial assistance for this study.

\section{Author Contributions}

Sajid Mahmood Sajid: Planning of study, standardisation and execution of lab protocols, collection and analysis of samples from experimental animals, analysis of data and write up of manuscript, Arfan Yousaf: Planning of study, analysis of data and write up of manuscript, Hamid Irshad: Planning and execution of study, analysis of data and write up of manuscript, Muhammad Arif Zafar: Planning of study and analysis of data, Saif ur Rehman: Planning of study and write up of manuscript. 


\section{References}

Abba Y, AA Bitrus, FFA Jesse, S Helmy, IU Hambali, MAM Lila, AW Haron (2017). Evaluation of protective effects of graded doses of lipopolysaccharide extracted from Pasteurella multocida Type B:2 against hemorrhagic septicemia in mice. Adv Anim Vet Sci 5:352-357

Ahmad TA, SS Rammah, SA Sheweita, M Haroun, LH El-Sayed (2014). Development of immunization trials against Pasteurella multocida. Vaccine 32:909-917

Archacka M, W Białas, R Dembczyński, A Olejnik, A Sip, D Szymanowska, M Rogodzińska (2019). Method of preservation and type of protective agent strongly influence probiotic properties of Lactococcus lactis: A complete process of probiotic preparation manufacture and use. Food Chem 274:733-742

Aschenbrenner M, U Kulozik, P Foerst (2012). Evaluation of the relevance of the glassy state as stability criterion for freeze-dried bacteria by application of the Arrhenius and WLF model. Cryobiology 65:308-318

Bassiouny I Ayatollah, AT El-Dakhly (2019). Efficacy of skimmed milk as stabilizer in comparison with lacto albumen sucrose in production of fowl and pigeon pox vaccines. Intl J Res Dev 4:123-131

Bellali S, JB Khalil, A Fontanini, D Raoult, JC Lagier (2020). A new protectant mediumpreserving bacterial viability after freeze drying. Microbiol Res 126454

Benkirane A,M De Alwis (2002). Haemorrhagic septicaemia, its significance, prevention and control in Asia. Vet Med-Czech 47:234-240

Berny JF, GL Hennebert (1991). Viability and stability of yeast cells and filamentous fungus spores during freeze-drying: Effects of protectants and cooling rates. Mycologia 83:805-815

Bhattacharya S (2018). Cryoprotectants and their usage in cryopreservation process. In: Cryopreservation Biotechnology in Biomedical and Biological Sciences, pp:7-19. IntechOpen, London, UK

Bolla PA, M de los Angeles Serradell, PJ de Urraza, GL De Antoni (2011). Effect of freeze-drying on viability and in vitro probiotic properties of a mixture of lactic acid bacteria and yeasts isolated from kefir. $J$ Dairy Res 78:15-20

Bora DP, V Bhanuprakash, G Venkatesan, V Balamurugan, M Prabhu, R Yogisharadhya (2015). Effect of stabilization and reconstitution on the stability of a novel strain of live attenuated orf vaccine. Asian $J$ Anim Vet Adv 10:365-375

Bora M, RW Yousuf, P Dhar, RP Singh (2018). An overview of process intensification and thermo stabilization for upscaling of Peste des petits ruminants' vaccines in view of global control and eradication. Vir Dis 29:285-296

Boyce JD, JY Chung, B Adler (2000). Pasteurella multocida capsule: Composition, function and genetics. J Biotechnol 83:153-160

Carvalho AS, J Silva, P Ho, P Teixeira, FX Malcata, P Gibbs (2004). Relevant factors for the preparation of freeze-dried lactic acid bacteria. Intl Dairy J 14:835-847

Chen D, D Kristensen (2009). Opportunities and challenges of developing thermostable vaccines. Expert Rev Vaccines 8:547-557

Conrad PB, DP Miller, PR Cielenski, JJ de Pablo (2000). Stabilization and preservation of Lactobacillus acidophilus in saccharide matrices. Cryobiology 41:17-24

Cota ALS, RG Alvim (2018). Effect of storage temperature on Streptococcus mutans viability. Rev Odontol UNESP 47:74-78

Crowe JH, LM Crowe, AE Oliver, N Tsvekova, W Wolkers, F Tablin (2001). The trehalose myth revisited: Introduction to a symposium on stabilization of cells in the dry state. Cryobiology 43:89-105

Das M, DP Isore, C Guha, U Biswas, A Chatterjee (2018). Comparative efficacy of cryoprotectant in the lyophilization of pigeon paramyxovirus-1 vaccine. Ind J Anim Res 52:173-174

De Alwis MCL (1992). Haemorrhagic septicaemia-a general review. Brit Vet $J$ 148:99-112

Detmer A, J Glenting (2006). Live bacterial vaccines-a review and identification of potential hazards. Microb Cell Fact 5:23-24

El-Jakee JK, SS Ali, SA El-Shafii, AM Hessain, AA Al-Arfaj, MI Mohamed (2016). Comparative studies for serodiagnosis of haemorrhagic septicaemia in cattle sera. Saudi J Biol Sci 23:48-53
Elliott GD, S Wang, BJ Fuller (2017). Cryoprotectants: A review of the actions and applications of cryoprotective solutes that modulate cell recovery from ultra-low temperatures. Cryobiology 76:74-91

Fonseca F, S Passot, O Cunin, M Marin (2004). Collapse temperature of freeze-dried Lactobacillus bulgaricus suspensions and protective media. Biotechnol Prog 20:229-238

Gehrke HH, K Pralle, WD Deckwer (1992). Freeze drying of microorganisms-influence of cooling rate on survival. Food Biotechnol 6:35-49

Guowei S, X Yang, C Li, D Huang, Z Lei, C He (2019). Comprehensive optimization of composite cryoprotectant for Saccharomyces boulardii during freeze-drying and evaluation of its storage stability. Prep Biochem Biotechnol 49:846-857

Gur E, D Biran, EZ Ron (2011). Regulated proteolysis in Gram-negative bacteria-how and when? Nat Rev Microbiol 9:839-848

Hubalek Z (2003). Protectants used in the cryopreservation of microorganisms. Cryobiology 46:205-229

Jain NK, I Roy (2009). Effect of trehalose on protein structure. Protein Sci $18: 24-36$

Jain A, R Jain, S Jain (2020). Preservation of Microorganisms: Stabs, Slants, Lyophilization and Cryopreservation. In: Basic Techniques in Biochemistry, Microbiology and Molecular Biology, $6^{\text {th }}$ edn. Humana, New York, USA

Kang MS, H Jang, MC Kim, MJ Kim, SJ Joh, JH Kwon, YK Kwon (2010). Development of a stabilizer for lyophilization of an attenuated duck viral hepatitis vaccine. Poult Sci $J$ 89:1167-1170

Kanmani P, RS Kumar, N Yuvaraj, KA Paari, V Pattukumar, V Arul (2011). Effect of cryopreservation and microencapsulation of lactic acid bacterium Enterococcus faecium MC13 for long-term storage. Biochem Eng J 58:140-147

Kaushik JK, R Bhat (2003). Why is trehalose an exceptional protein stabilizer? An analysis of the thermal stability of proteins in the presence of the compatible osmolyte trehalose. J Biol Chem 278:26458-26465

Lacroix C, S Yildirim (2007). Fermentation technologies for the production of probiotics with high viability and functionality. Curr Opin Biotechnol 18:176-183

Latif MZ, K Muhammad, R Hussain, F Siddique, I Altaf, M Anees, M Farooq (2018). Effect of stabilizers on infectivity titer of freeze dried peste des petits ruminants virus vaccine. Pak Vet $J$ 38:169-170

Leslie SB, E Israeli, B Lighthart, JH Crowe, LM Crowe (1995). Trehalose and sucrose protect both membranes and proteins in intact bacteria during drying. Appl Environ Microbiol 61:3592-3597

Liu H, SW Cui, M Chen, Y Li, R Liang, F Xu, F Zhong (2019). Protective approaches and mechanisms of microencapsulation to the survival of probiotic bacteria during processing, storage and gastrointestinal digestion: A review. Crit Rev Food Sci Nutr 59:2863-2878

Mahapatra M, M Selvaraj, S Parida (2020). Comparison of immunogenicity and protective efficacy of PPR live attenuated vaccines (Nigeria 75/1 and Sungri 96) administered by intranasal and subcutaneous routes Vaccines 8; Article 168

Malik KA, B Beyersdorf-Radeck, RD Schmid (1993). Preservation of immobilized bacterial cell-matrix by drying for direct use in microbial sensors. World J Microbial Biotechnol 9:243-247

Mariner JC, J Gachanja, SH Tindih, PA Toye (2017). Thermostable presentation of the live, attenuated peste des petits ruminants vaccine use in Africa and Asia. Vaccine 35:3773-9

Mensink MA, HW Frijlink, K van der Voort Maarschalk, WL Hinrichs (2017). How sugars protect proteins in the solid state and during drying (review): Mechanisms of stabilization in relation to stress conditions. Eur J Pharm Biopharm 114:288-295

Miles AA, SS Misra, JO Irwin (1938). The estimation of the bactericidal power of the blood. Epidemiol Infect 38:732-749

Morgan CA, N Herman, PA White, G Vesey (2006). Preservation of micro-organisms by drying; a review. J Microbiol Methods 66:183-193

Nireesha GR, L Divya, C Sowmya, N Venkateshan, MN Babu, V Lavakumar (2013). Lyophilization/freeze drying-a review. Intl $J$ Novel Trends Pharm Sci 3:87-98 
Oslan SNH, M Halim, NA Ramle, MZ Saad, JS Tan, MR Kapri, AB Ariff (2017). Improved stability of live attenuated vaccine gdhA derivative Pasteurella multocida B: 2 by freeze drying method for use as animal vaccine. Cryobiology 79:1-8

Pansare SK, SMPatel(2019). Lyophilization process design and development: A single-step drying approach. J Pharma Sci 108:1423-1433

Passot S, S Cenard, I Douania, IC Trelea, F Fonseca (2012). Critical water activity and amorphous state for optimal preservation of lyophilised lactic acid bacteria. Food Chem 132:1699-1705

Peiren J, J Buyse, P De Vos, E Lang, D Clermont, S Hamon, MC Macián (2015). Improving survival and storage stability of bacteria recalcitrant to freeze-drying: A coordinated study by European culture collections. Appl Microbiol Biotechnol 99:3559-3571

Saarela M, G Mogensen, R Fonden, J Matto, T Mattila-Sandholm (2000). Probiotic bacteria: Safety, functional and technological properties. $J$ Biotechnol 84:197-215

Saarela M, I Virkajärvi, HL Alakomi, T Mattila-Sandholm, A Vaari, T Suomalainen, J Mättö (2005). Influence of fermentation time, cryoprotectant and neutralization of cell concentrate on freeze-drying survival, storage stability, and acid and bile exposure of Bifidobacterium animalis ssp. lactis cells produced without milk-based ingredients. J Appl Microbiol 99:1330-1339

Saclier M, R Peczalski, J Andrieu (2010). Effect of ultrasonically induced nucleation on ice crystals' size and shape during freezing in vials. Chem Eng Sci 65:3064-3071

Sarah SO, M Zamri-Saad, Z Zunita, AR Raha (2006). Molecular cloning and sequence analysis of gdhA gene of Pasteurella multocida B: 2. J Anim Vet Adv 5:1146-1149

Sarah SO (2007). Construction of an attenuated Pasteurella multocida B:2 by mutation in the gdh A gene, Master of Science Thesis, Universiti Putra, Malaysia

Schoug Å, J Olsson, J Carlfors, J Schnürer, S Håkansson (2006). Freezedrying of Lactobacillus coryniformis Si3-effects of sucrose concentration, cell density and freezing rate on cell survival and thermophysical properties. Cryobiology 53:119-127

Shivachandra SB, KN Viswas, AA Kumar (2011). A review of hemorrhagic septicemia in cattle and buffalo. Anim Health Res Rev 12:67-82
Shokri S, MK Shahkarami, A Shafyi, A Mohammadi, F Esna-ashari, A Hamta (2019). Evaluation of the thermal stability of live-attenuated Rubella vaccine (Takahashi strain) formulated and lyophilized in different stabilizers. J Virol Methods 264:18-22

Singh AP, SK Gupta, P Thomas, VP Singh (2010). Detection of Pasteurella multocida in preserved morbid tissue material by polymerase chain reaction. Ind J Comp Microbiol Immunol Infect Dis 31:14-16

Stephan DA, PM Da Silva, IL Bisutti (2016). Optimization of a freezedrying process for the biocontrol agent Pseudomonas spp. and its influence on viability, storability and efficacy. Biol Cont 94:74-81

Tang XC, MJ Pika (2004). Design of freeze-drying processes for pharmaceuticals: Practical advice. Pharm Res 21:191-200

Winters RD, WC Winn (2010). A simple, effective method for bacterial culture storage: A brief technical report. J Bacteriol Virol 40:99-101

Zayed G, YH Roos (2004). Influence of trehalose and moisture content on survival of Lactobacillus salivarius subjected to freeze-drying and storage. Process Biochem 39:1081-1086

Zeng Y, H Fan, G Chiueh, B Pham, R Martin, D Lechuga-Ballesteros, CR Middaugh (2009). Towards development of stable formulations of a live attenuated bacterial vaccine: A preformulation study facilitated by a biophysical approach. Hum Vacc 5:322-331

Zhang B, Y Hui (2017). Optimization of cryoprotectants for Streptococcus thermophilus during freeze-drying using Box-Behnken experimental design of response surface methodology. Emir $J$ Food Agric 256-263

Zhang Z, YX Yu, YG Wang, XX Wei, MJ Liao, XJ Rong, J Chen (2020). Development of a new protocol for freeze-drying preservation of Pseudoalteromonas nigrifaciens and its protective effect on other marine bacteria. Electron J Biotechnol 44:1-5

Zhao G, G Zhang (2005). Effect of protective agents, freezing temperature, rehydration media on viability of malolactic bacteria subjected to freeze-drying. J Appl Microbiol 99:333-338

Zhao G, H He, H Wang (2019). Use of a recombinase polymerase amplification commercial kit for rapid visual detection of Pasteurella multocida. BMC Vet Res 15; Article 154 